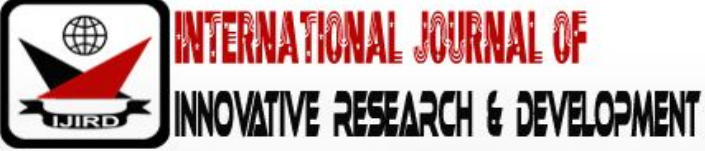

ISSN 2278 - 0211 (Online)

\section{Agricultural Productivity and Poverty Reduction in Nigeria (2000-2016)}

\author{
Dr. Ayodeji, Emmanuel, A \\ Senior Lecturer, Department of Banking and Finance \\ Afe Babalola University, Ado Ekiti, Ekiti State, Nigeria \\ Oladokun, Bamikole Samuel \\ Post Graduate Student, Department of Banking and Finance, \\ Afe Babalola University, Ado-Ekiti, Ekiti State, Nigeria
}

\begin{abstract}
:
The study examined the effects of agricultural productivity on poverty (and hunger) reduction in Nigeria within the temporal scope of 2000 - 2016. Secondary data were sourced from Central Bank of Nigeria (CBN) statistical bulletins and World Bank Development Indicators. On the anchor of resource use efficiency theory, the study employed Agriculture Budget Allocation (AGRBA), Commercial Banks Credit to Agriculture (CBCA), Micro Finance Banks Credit to Agriculture (MFBCA) and Food Production Index (FPI) to proxy agricultural productivity, and Human Development Index (HDI) was used to proxy poverty and hunger. Data were estimated using Johansen co-integration test and regression analysis. It was found that, long-run relationship exists between agricultural productivity and poverty reduction in Nigeria. It was also found that, agriculture budget allocation and commercial banks credit to agriculture did not translate to poverty and hunger reduction in Nigeria, but both microfinance banks credit to agriculture and food production index contributed to poverty and hunger reduction in Nigeria. It was therefore recommended that, government should increase agricultural sector budgetary allocation, and this should be attributed to encouraging unemployed youths and unskilled labour in the country to embrace agribusiness so as to increase agricultural productivity in Nigeria. This should be monitored to ensure that they are not diverted to other sectors, and are used for the purposes for which they are meant, so that the funds will not end up in the hands of greedy people within the sector. Not only that, regulatory authorities of the Nigerian banking sub-sector should ensure that, commercial banks credit to agricultural sector get to the right targets within the purview of sectorial credit portfolio.
\end{abstract}

Keywords: Agricultural productivity, poverty and hunger

\section{Introduction}

Developing economies are caught in the web of vicious cycle of poverty, as they manifest low income, low savings and low investments, which result in a number of economic and social problems, such as poverty and hunger, unemployment and social vices, corruption and insecurity. Among these, poverty and hunger are significant, and are 'Siamese twins', as they are inseparable conditions. From the Annual Abstract of Statistics(2016), it is obtainable that, these conditions are prevalent in Nigeria, particularly in the North-West, North-East and North-Central, recording 59\%$77 \%$ of cases of being food poor, absolutely poor, relatively poor and dollar per day poor.

Poverty could be said to be endemic in the Nigerian economy, as the situation has been existing for long. Take for instance, the publication of the Federal Office of Statistics (1996) reveals that, poverty has become so enormous and pandemic to the extent that, it has overwhelmed a significant proportion of the Nigerian population. Also, Abiola and Olaopa (2008) noted that, it is an incontrovertible fact that, poverty has been a socio-economic menace in the Nigerian society. This condition results in hunger or food insecurity, malnutrition or malnourishment, disease or illness, low life expectancy or shortened life span, ignorance or illiteracy, lack of access to quality education and good health care, unemployment and social vices, and general level of human hopelessness and depression.

Poverty and hunger, in the life of an individual, negatively affect his/ her performance in an organization, and lower organizational performances have undesirable effects on the economy of a nation. These conditions cause malnourishment, increase susceptibility to illness, bring inability to pay children's school fees, and worsen children's academic performance. Their effects on the organization include reduction in labour productivity, and reduction in the willingness to undertake risky but more profitable investments, which would, in turn, affect organizational financial performance. However, their effects on the nation include corruption, social vices, and insecurity (Sumiter, 2002; Otaha, 2013).

Consequently, successive governments, in Nigeria, have come up with various programmes and policies, which aim at alleviating poverty from the land. These, among others, include agricultural development programmes and policies, microfinance policy, youth and women empowerment programmes. Prominent among these are agricultural development 
programmes and policies, which aim at achieving two main objectives; the first being to ensure adequacy of food reserve in the country in order to forestall the threat of food insecurity. As a result of this, where domestic agricultural production could not meet up with aggregate demand for food from the Nigerian populace, the country had to import food to bridge the gap. The second, being to ensure improvement in the living standards of the Nigerian populace; thus, reducing poverty and hunger in the land (Auta \& Dafwang, 2010). This, essentially, is the first of the seventeen Sustainable Development Goals, which is "reduction of poverty and hunger in all nations of the world".

Nigeria's agricultural development programmes fall within two eras, with the Structural Adjustment Programme (SAP) being the dividing line, so that, we have the pre-SAP era and post-SAP era. Programmes which fall within the preSAP era include: Agricultural Development Projects (ADPs), 1972; National Accelerated Food Production Programme, 1972; Agricultural Development Banking that established Nigerian Agricultural Bank (NAB), 1973, which was renamed as Nigerian Agricultural and Cooperative Bank (NACB), 1978; National Seed Service (NSS), 1975; Operation Feed the Nation (OFN), 1976;River Basin Development Authorities (RBDAs), 1976; Agricultural Credit Guarantee Scheme Fund (ACGSF), 1977; Green Revolution Programme,1979; Agricultural and Rural Management Training Institute (ARMTI), 1980; etc. (World Bank, 1996; Daneji, 2011; Omonijo, Toluwase, Oludayo \& Uche, 2015).

However, agricultural development programmes falling within the post-SAP era include: Directorate of Foods, Roads and Rural Infrastructure (DFFRI), 1987; Nigerian Agricultural Insurance Company (NAIC), 1987; National Centre for Agricultural Mechanization (NCAM),1990; National Agricultural Land Development Authority (NALDA), 1992; Consolidation of Nigerian Agricultural and Cooperative Bank (NACB), Peoples Bank of Nigeria (PBN), and Family Economic Advancement Programme (FEAP) into Nigerian Agricultural Cooperative and Rural Development Bank (NACRDB) in 1999, and rebranding it as Bank of Agriculture (BOA) in 2010. Root and Tuber Expansion Programme (RTEP), 2000; Comprehensive African Agricultural Development Programme (CAADP), 2002, which is an integral part of the New Partnership for Africa's Development (NEPAD); National Economic Empowerment and Development Strategy (NEEDS), 2004. Agricultural Borrowers Programme (ABP), 2015; Presidential Fertilizer Initiative (PFI), 2016; Youth Farm Lab, 2016 (YFL); Presidential Economic Diversification Initiative (PEDI), 2017; Food Security Council (FRC), 2018 (World Bank, 1996;Daneji, 2011; Omonijo et al 2015; Adebayo, 2017; Toromade, 2018).

With all these programmes and policies, which aim at developing agricultural sector in Nigeria for the achievement of agricultural productivity, the spate of food insecurity and poverty still remains alarming and unabated, and as such, these programmes and policies have not achieved expected results (Diano, Hazell \& Thurlow, 2010; Gate, 2014; Omonijo et al, 2015; Udeh \& Nwachukwu, 2015). As a direct consequence of this, several studies have been carried out on the link between agricultural productivity and poverty (and hunger) reduction in Nigeria. Some of these studies identified agriculture as a solution to poverty and hunger in Nigeria, but only discussed the contributions of agriculture to the economy without looking at how agricultural productivity can be enhanced.

For examples, Medugu(2006) looked at the policy aspect of agriculture in reducing poverty and hunger in Nigeria, Oriola(2009) considered irrigation technology for food production (i.e. agricultural output), and Okunola(2016) examined rural positioning of agriculture for food production. Worse still, most of the works on agriculture and poverty reduction, in Nigeria,are position papers, which only employed qualitative methodology. Also, little research attention has been given to the aspect of finance as a factor for enhancing agricultural productivity as a basis for achieving poverty and hunger reduction in Nigeria. Consequently, this study was undertaken to examine the effects of agricultural productivity on poverty and hunger reduction in Nigeria. Thus, specifically, the study was initiated to investigate the dynamic relationship between agricultural productivity and poverty reduction in Nigeria.

\section{Literature Review}

\subsection{Conceptual Clarification}

Agricultural productivity is the varying proportions of agricultural output to one or all of agricultural inputs, such as land, labour and capital (Hanumamanthapa, 2014). It refers to the ratio of the index of total output to the index of inputs in agricultural production; as such, it measures the efficiency in agricultural input utilization in the generation of agricultural output (Food and Agriculture Organisation [FAO], 2015). There are two measures of agricultural productivity; these are partial and total measures. While the partial measures consider the index of agricultural output to index of a unit of agricultural input, the total measureconsiders the index of agricultural outputs to index of total agricultural inputs. Therefore, agricultural output per unit of land would interpret agricultural land productivity; agricultural output per unit of labour would interpret agricultural labour productivity; and agricultural output per unit of capital would interpret agricultural capital productivity; and total measure of agricultural productivity is agricultural total factor productivity [TFP] (FAO, 2015).

Changes in partial measures of agricultural productivity may result from mechanization, output mix, crop rotation, improved seedlings and use of fertilizers. However, changes in agricultural total factor productivity may result from improved technology, changes in agricultural research and development, changes in parameters for measuring inputs and outputs, improved infrastructural facilities, and changes in environmental conservation policies of the government (Ahearn, Yee, Ball \& Nehring, 1998).

It is instructive to note that, each of the partial agricultural productivity is referred to as Yield, so that agricultural land productivity is agricultural land yield; agricultural labour productivity is agricultural labour yield; and agricultural capital productivity is agricultural capital yield. The usefulness of the 'yield approach' of the partial measures is that, it is used to assess the effectiveness of a new technology or a new production practice. Also, labour productivity is used to compare productivity across different sectors of an economy or within the same sector across different economies. Not 
only that, agricultural labour productivity is used to assess the living standards of the rural dwellers, as it indicates the capability of the farmers or rural dwellers to earn income from agricultural produce over and over again (FAO, 2015). As such, agricultural productivity should have a direct bearing on poverty and hunger reduction.

Poverty is a condition of lack, insufficiency or inadequacy of financial resources with which to satisfy basic human needs of quality food, clothing and shelter, as well as portable water and health services; thus, culminating into deprivation, restriction of choices, and poor living standards (United Nations Human Development Report, 1998; Korankye, 2014). In the same vein, the Annual Abstract of Statistics (2010) defined poverty as the lack of income required to ensure access to necessities of life, including access to health, education, and other services. However, hunger is a direct manifestation of poverty, which includes lack of food, clothing and shelter, and lack of access to health services. As much as poverty and hunger are both conditions of lack, the basic distinction between them is that, while poverty is lack of purchasing power (financial resources) to satisfy basic needs, hunger is the lack of those basic needs; hence, there cannot be hunger without poverty.

Similarly, food insecurity is a state of being without the right quantity and quality of nutritious food for the proper use of the body system within the domain of nutrition and health (FAO, 2010; Otaha, 2013). Therefore, food security is the state of having reliable access to the right quantity and quality nutritious food by all people to enable them live a healthy life at all times (World Food Programme, 2013). A country is therefore said to be food secured when a large proportion of her population have access to the right quantity and quality of nutritious food consistent with good living and decent existence at all times (Reutlinger, 1985; Idachaba, 2004). This implies that, for food security to be achieved, food should not only be available, but it should also be accessible to the majority of the people. Availability of food is a function of food production, consumer prices and market dynamics (Honfoga \& Van, 2003), while accessibility to food is a function of consumer income (i.e. purchasing power) and budget constraint. Budget constraint is defined as the quantity (amount) of a bundle or basket of goods that a consumer can buy given his money income level and market price (Onipede \& Ayodeji, 2005).

Sustainable food security, however, is the state of having access to the right quantity and quality food to meet dietary needs for an active (or a productive) healthy life at present as well as the capacity to make provision for the future (Abudullahi, 2008); Amaka, Kelechukwu \& Olisa, 2016). Thus, the indices of sustainable food security include quantity (availability), quality (of nutritional content), accessibility (affordability), and environmental conservation. These imply availability of food supply; quality of nutritional content; affordability of food supplied; and conservation of the environment for meeting future dietary needs.

\subsection{Theoretical Framework}

This study is anchored on the Resource Use Efficiency theory, which states that, when resources are efficiently utilized, the wealth (or income) of the nation is increased; and as such, the income per head of the population (i.e. per capita income) is increased and the living standards of the people is improved. In other words, efficient utilization of resources would lead to improvement in the living standards of the people; thus leading to reduction in the level of poverty and hunger. At any rate, efficiency in the utilization of resources implies productivity. By this, at any given level of input, the maximum (i.e. highest) possible output is achieved; and at any given level of output, the minimum (i.e. least) possible input is used (Onipede \& Ayodeji, 2005).

Resource use efficiency is the economists' viewpoint of efficient utilization of resources. It implies that, managers and employees owe their employers the duty to take reasonable care in utilizing the firm's resources. Resources are efficiently utilized, when they are used to yield maximum results i.e. obtaining the highest possible output at the lowest (least) possible cost combination of factor inputs: when this is achieved, productive efficiency is achieved. Not only that, resources are also said to be efficiently utilized, when managers put in place the right combination of factor inputs (i.e. resources) in achieving the maximum possible output, such that minimum possible resources are allocated to derive maximum possible satisfaction or output: when this is achieved, allocative efficiency is achieved (Ayodeji, 2011). Productive efficiency is, essentially, the concept of productivity, which is a measure of efficiency in the utilization of a given level of input to generate output over and over again. In sum, resource use efficiency implies that, productivity would lead to improvement in people's standard of living, and hence, poverty reduction. When this theory is applied to agricultural productivity, it is expected that, agricultural productivity would bring about poverty and hunger reduction.

\subsection{Empirical Review}

Iheke and Arikaibe(2012) evaluated the impact of agricultural intensification on poverty alleviation in Nigeria, using Imo State as the study area. Primary data were sourced from a sample of 120 farm householders through the instrumentality of questionnaire across three rural local government areas. The study employed logit regression with chow's test to analyse the data gathered, and found that, there is a significant positive relationship between agricultural intensification and poverty reduction in Imo State, Nigeria. It also found that, poverty is more prominent with farm householders who do not practice agricultural intensification.

Similarly, Eseyin and Oni (2016) investigated the effects of investments in agricultural sector on poverty reduction in Nigeria within the period 1985 - 2012. The study sourced data from Central Bank of Nigeria Statistical Bulletin and World Bank data base, and estimated them with error correction model. It found a long-run relationship between investments in agricultural sector and poverty reduction in Nigeria. It also found that, agricultural productivity is more sensitive to capital and labour inputs, and that, private investment financing, through the Agricultural Credit Guaranteed Scheme Fund(ACGSF), has statistically significant positive impact on agricultural productivity, leading to poverty reduction in Nigeria. 
Still, Okunola (2016) evaluated rural economy positioning for implementation of sustainable development goals. Using qualitative approach methodology, the study found that,the class struggle between the rich and the poor was heightened with the gap being widened by the introduction of structural adjustment programme; and to solve this socioeconomic problem, several economic policies were advanced, which yielded no positive results. It also found that, repositioning and refocusing on rural areas, by providing them with adequate infrastructural facilities, are capable of solving the problem of food insecurity in Nigeria.

Following this, Ogundipe, Oduntan, Ogunniyi and Olagunju(2017) investigated the relationship between agricultural production, poverty reduction and inclusive growth in Africa within a temporal scope of 1991-2015. The study built three models with rural poverty, urban poverty and dollar poverty as respective dependent variables, and the independent variables employed were GDP per capita, domestic credit to private sector, agricultural value added per worker, and food production index. Using panel data approach, which was estimated through the use of Generalized Moment Method (GMM) of analysis, it found that, GDP per capital significantly contributed to reduction in urban poverty and dollar poverty while domestic credit to private sector significantly contributed to reduction of, not only urban poverty and dollar poverty, but also rural poverty, on which it had the largest impact. It also obtained that, while agricultural value added per worker significantly contributed to reduction in rural poverty and unemployment, food production index did not significantly contribute to rural poverty reduction.

Analogous to the above, Katsushi (2017) assessed the effects of agricultural transformation on poverty, hunger, inequality and productivity in 105 countries over four decades. The study sourced secondary data from World Development Indicators (WDIs) and World Bank poverty rates. Poverty was proxied by poverty head count ratio at $\$ 1.90$; food security was proxied by agricultural total food production; and agricultural transformation was proxied by commercialization index, agricultural openness index, and product diversification index. Using panel model, the study found that, transformation and growth of agricultural productivity significantly reduced national, rural and urban poverty; and agricultural openness significantly improved food security. It also found that, except for Latin America, product diversification reduced agricultural productivity, but commercialization did not increase agricultural productivity.

However, Korankye (2014) investigated the causes of poverty in Africa. Using qualitative approach methodology, the study found that, poverty is endemic in Africa, and it is a product of many factors, such as individuals' unemployment due to lack of education, knowledge, relevant skills and proper training. It also found social factors like unending conflicts, wars and cultural affinity as causes of poverty. Not only that, it found the following institutional problems to contribute to poverty: lack of good governance, inefficient allocation and utilization of resources, lack of infrastructural facilities, poor government policies, and poor World Bank and International Monetary Fund (IMF) policies.

Also, Renuka and Vincent (2015) assessed the link between poverty and food security in Vietnam between 2010 and 2015, using latent class model. The study sourced primary data through2010 Vietnam Household Living Standards Survey (VHLSS) on 9399 households from six rural and urban regions, and obtained self-evaluation of food sufficiency in the 2010 VHLSS. Estimating the data gathered through the use of regression analysis, the study found that, the link between poverty and food security is weak in the rural areas while it is strong in the urban areas.

Not only that, Udofia and Essang (2015) investigated the effects of agricultural expenditure on poverty alleviation in Nigeria from 1980 to 2012. Secondary data were sourced from Central Bank of Nigeria Statistical Bulletins and World Development Indicators, and were analyzed using ordinary least square method. The study found that, government expenditure, agricultural import value and agricultural export value had significant positive relationship with agricultural gross domestic product, while agricultural credit facilities had a negative relationship with it. It also found that, unemployment, government expenditure, agricultural output and electricity consumption had negative relationship with poverty index while population had a positive relationship with it.

Nevertheless, Otaha (2013) examined food insecurity and the way forward in Nigeria. The study employed qualitative research methodology, and found that, food insecurity has been a prevalent problem in Nigeria since the oil boom of early 1970s which brought about the neglect of agricultural sector by individuals, firms and governments in the areas of agricultural production, exportation and development. It also found that, government policies of devaluation of Naira and trade liberalization within the ambit of neo-liberal economic policies, have heightened the problem. Not only that, it found lack of capital, skills, energy and other viable ingredients to be the major causes of poverty.Stemming from this, Matemilola and Elegbede (2017) examined the challenges of food security in Nigeria. Using qualitative approach methodology, the study found that, the neglect of agricultural sector for oil exploration and production caused food insecurity, because a fraction of the population benefited from the oil wealth while majority of the population suffered misfortune of food insecurity as they can hardly afford the rising prices of imported goods.

As such, Nwankpa (2017) examined the effects of sustainable agricultural development on hunger and poverty reduction in South Western Nigeria, using qualitative research methodology. The study found that, rural-urban drift, owing to distribution of infrastructure and employment opportunities, had led to reduction in agricultural productivity in Nigeria. It also found that, low investment in agriculture, lack of access to credit, and diversion of government subsidized agricultural inputs to wrong targets contributed to reduction in agricultural productivity in Nigeria.

\section{Methodology}

Relevant data for this study were sourced from Central Bank of Nigeria (CBN) Annual Reports, CBN Statistical Bulletins, National Bureau of Statistics (NBS)Reports, Food Production Index, and World Development Indicators. The preliminary tests carried out were Augmented Dickey-Fuller (ADF) unit roots test andBreusch Pagan normality test. Data were estimated using Johansen co-integration test and multiple regression analysis. 
In this study, agricultural productivity was proxied by Agriculture Budget Allocation (AGRBA), Commercial Banks Credit to Agriculture (CBCA), Micro Finance Banks Credit to Agriculture (MFBCA) and Food Production Index (FPI) while Human Development Index (HDI) was employed to proxy poverty and hunger. The employment of HDI was based on the fact that, it is an economic model that considers the intrinsic personal factors of the economy, which include literacy rates, employment rates, life expectancy, decent standard of living, and poverty rates (Human Development Reports, 2016).

The model for the study is therefore stated thus:

HDI $\quad=$ (AGRBA, CBCA, MFBCA, FPI) $\quad$...........1

In an explicit form, the model is thus stated as:

$\mathrm{HDI}_{\mathrm{it}}=\beta \mathrm{o}+\beta_{1} \mathrm{AGRBA}_{\mathrm{it}}+\beta_{2} \mathrm{CBCA}_{\mathrm{it}}+\beta_{3} \mathrm{MFBCA}_{\mathrm{it}}+\beta_{4} \mathrm{FPI}_{\mathrm{it}}+\mu_{\mathrm{i}} \quad \ldots \ldots \ldots \ldots .2$

Where:

HDI=Human Development Index;AGRBA =Agriculture Budget Allocation; $\mathrm{CBCA}=$ Commercial Banks Credit to Agriculture; MFBCA = Micro Finance Banks Credit to Agriculture; FPI= Food Production Index; $\beta_{0}=$ Constant term; $\beta_{1}-\beta_{4}=$ Parameters to be estimated, which are coefficients of the independent variables; $\mu_{i}=$ Stochastic Error term

\section{Results and Findings}

\subsection{Augmented Dickey Fuller Test}

The standard Augmented Dickey-Fuller (ADF) unit root test was used to check for the order of integration of the variables. The results obtained are presented in Table 1 below. Based on the ADF test statistic, it was observed that, all the variables, in the study, were not stationary at level $\mathrm{I}(0)$, but became stationary at first difference I(1), when their respective p-values are less than 0.05 , that is, $5 \%$ level of significance. The null hypothesis of the ADF test is that,the series is non-stationary, that is, it contains a unit root. As the series became stationary at first difference, the null hypothesis was thereforerejected, and the alternate hypothesis was accepted, as it states that the series is free from unit roots. The rejection is based on McKinnon (1996) critical values. The lag length are selected based on Schwartz Information Criterion (SIC).

\begin{tabular}{|c|c|c|c|c|c|}
\hline Variables & ADF & Critical Value & Difference & Lag & Prob \\
\hline FPI & -1.8576 & -3.0988 & $\mathrm{I}(0)$ & 2 & 0.3403 \\
\hline DFPI & -8.2427 & -3.081 & $\mathrm{I}(1)$ & 2 & 0.000 \\
\hline HDI & -1.9264 & -3.0655 & $\mathrm{I}(0)$ & 2 & 0.313 \\
\hline DHDI & -3.9768 & -3.081 & $\mathrm{I}(1)$ & 2 & 0.0097 \\
\hline AGRB & -2.1787 & -3.0655 & $\mathrm{I}(0)$ & 2 & 0.2203 \\
\hline DAGRB & -4.4992 & -3.0988 & $\mathrm{I}(1)$ & 2 & 0.0042 \\
\hline MFBCA & -1.0371 & -3.0655 & $\mathrm{I}(0)$ & 2 & 0.7129 \\
\hline DMFBCA & -4.8969 & -3.081 & $\mathrm{I}(1)$ & 2 & 0.0018 \\
\hline CBCA & -0.9905 & -3.0655 & $\mathrm{I}(0)$ & 2 & 0.994 \\
\hline DCBCA & -3.9433 & -3.081 & $\mathrm{I}(1)$ & 2 & 0.0103 \\
\hline
\end{tabular}

Table 1: Results of Augmented Fuller (ADF) Dickey Stationary Test

Source: Author's Computation, 2018

\subsection{Breusch Pagan for Normality Test}

For normality test, the study employed Breusch Pagan Test to check if the series is normally distributed. The results of the test are presented in Table 2 below, which shows that, the series is normally distributed, as F-statistics of 0.2898 and p-value of 0.878 are greater than 0.05 , that is, $5 \%$ level of significance, indicating that the series has no conditional heteroskcedacity in the distribution of residual. The study, therefore, accepts the null hypothesis that the series are free from the presence of heteroskceda city which assumes homoskedasticity.

\begin{tabular}{|c|c|c|c|}
\hline \multicolumn{4}{|c|}{ Heteroskedasticity Test: Breusch-Pagan-Godfrey } \\
\hline F-statistic & 0.289859 & Prob. F(4,10) & 0.878 \\
\hline Obs*R-squared & 1.558459 & Prob. Chi-Square(4) & 0.8162 \\
\hline Scaled explained SS & 0.46142 & Prob. Chi-Square(4) & 0.9771 \\
\hline
\end{tabular}

Table 2: Summary of Heteroskedasticity Test

Source: Author's Computation, 2018

\subsection{Co-Integration Test}

The study employed Johansen co-integration test to investigate the existence of long-run relationship between the variables employed. This was done by comparing the Trace-Statistic results with the critical value results. This is presented in Table 3 below, which indicates that, there is one co-integration vector between the variables employed. This is confirmed (at none) by the Trace Statistic value of 48.67282, which is greater than the critical value of 47.85613 at $5 \%$ (0.05) level of significance. Alternatively, it is confirmed by the Maximum Eigen statistic value of 34.37905, which is greater than the critical value of 27.58434 at $5 \%(0.05)$ level of significance. It is confirmed further by the p-value of 0.0057, which is less than 0.05 (i.e. $5 \%$ ) level of significance. Therefore, it was found that, a long-run relationship exists between agricultural productivity and poverty reduction, within the period under review, in Nigeria. 


\begin{tabular}{|c|c|c|c|c|c|c|c|}
\hline Hypothesized & Trace & $\mathbf{0 . 0 5}$ & & Hypothesized & Max-Eigen & $\mathbf{0 . 0 5}$ & \\
\hline No. of CE(s) & Statistic & Critical Value & Prob.** & No. of CE(s) & Statistic & Critical Value & Prob.** \\
\hline None* & 48.67282 & 47.85613 & 0.0418 & None* & 34.37905 & 27.58434 & 0.0057 \\
\hline At most 1 & 14.29377 & 29.79707 & 0.8237 & At most 1 & 9.975731 & 21.13162 & 0.7470 \\
\hline At most 2 & 4.318037 & 15.49471 & 0.8763 & At most 2 & 4.260749 & 14.26460 & 0.8309 \\
\hline At most 3 & 0.057288 & 3.841466 & 0.8108 & At most 3 & 0.057288 & 3.841466 & 0.8108 \\
\hline
\end{tabular}

Table 3: Summary of Co-Integration Test among the Variables

Source: Author's Computation, 2018

\subsection{Regression Analysis and Interpretation}

Table 4 below displays the summarized regression results from the model estimated. The model shows the relationship between agricultural productivity (proxied by agriculture budget allocation, commercial banks credit to agriculture, microfinance bank credit to agriculture and food production index) and poverty reduction (proxied by human development index). It was found that, the coefficient of determination $\left(\mathrm{R}^{2}\right)$ stood at approximately 0.6280 ,which indicates that a change in human development index is explained, to the tune of $62.80 \%$, by the independent variables (proxies of agricultural productivity) while $37.20 \%$ variation remains unexplained, or are accounted for by other factors not captured in the model. The adjustedR ${ }^{2}$, of approximately $47 \%$, indicates the true behaviour of the dependent variable (human development index) in relation to changes in the independent variables, thus judging the goodness of the model.

Testing for the significance of each variable employed in the model; it was found that, DLAGRBA and DLCBCA are positively signed with 0.010129 and 0.021803 respectively, but are not significant as their p-values of 0.1289 and 0.2387 , respectively, are higher than 0.05 , that is, $5 \%$ level of significance. The implication of these is that, a unit increase in agriculture budget allocation and a unit increase in commercial banks credit to agriculture will insignificantly increase poverty and hunger in Nigeria. However, DLMFBCA has negative coefficient of -0.01753 with a significant $p$-value of 0.0042 , which is less than 0.05 , that is, $5 \%$ level of significance, while DFPI has a negative coefficient of -0.000795 and insignificant p-value of 0.3113 , which is greater than 0.05 , that is, $5 \%$ level of significance. These imply that, a unit increase in microfinance banks credit to agriculture will significantly bring about a reduction in poverty and hunger in Nigeria, while a unit increase in food production index will insignificantly bring about a reduction in poverty and hunger in Nigeria.

The overall significance of the model was also carried out using F- statistics. This was done by comparing the Fcalculated figure with F- tabulated figure. The F- calculated figure of 4.221 is greater than the F- tabulated figure of 2.84. This is a clear indication that the whole regression is statistically significant; hence, the overall null hypothesis, which states that, there is no significant relationship between agricultural productivity and poverty reduction in Nigeria, was rejected, and the alternate hypothesis was accepted, as it states that, there is significant relationship between agricultural productivity and poverty reduction in Nigeria.

The Durbin Watson test result of 2.70 reveals that, there is presence of serial correlation between the variables employed because this is greater than the threshold of 2.0; however, this was corrected with the Hac-Newey West test, showing a Wald F-statistics test result of 6.25 with probability value of 0.008 , which is statistically significant, as it is less than 0.05 , that is, $5 \%$ level of significance.

\begin{tabular}{|c|c|c|c|c|}
\hline Variable & Coefficient & Std. Error & t-Statistic & Prob. \\
\hline DLAGRB(-1) & 0.010129 & 0.006119 & 1.655246 & 0.1289 \\
\hline $\operatorname{DLCBCA}(-1)$ & 0.021803 & 0.017399 & 1.253108 & 0.2387 \\
\hline $\operatorname{DLMFBCA}(-1)$ & -0.01753 & 0.004753 & -3.68795 & 0.0042 \\
\hline DFPI(-1) & -0.000795 & 0.000746 & -1.066428 & 0.3113 \\
\hline $\mathrm{C}$ & -0.026127 & 0.026518 & -0.985233 & 0.3477 \\
\hline $\begin{array}{l}\text { R-squared } \\
\text { Adjusted }\end{array}$ & 0.628038 & \multicolumn{2}{|c|}{ Mean dependent var } & 0.0048 \\
\hline R-squared & 0.479254 & \multicolumn{2}{|c|}{ S.D. dependent var } & 0.024305 \\
\hline S.E. of regression & 0.017539 & \multicolumn{2}{|c|}{ Akaike info criterion } & -4.987543 \\
\hline Sum squared resid & 0.003076 & \multicolumn{2}{|c|}{ Schwarz criterion } & -4.751527 \\
\hline Log likelihood & 42.40658 & \multicolumn{2}{|c|}{ Hannan-Quinn criter. } & -4.990057 \\
\hline F-statistic & 4.221123 & \multicolumn{2}{|c|}{ Durbin-Watson stat } & 2.700777 \\
\hline Prob(F-statistic) & 0.029479 & \multirow{2}{*}{\multicolumn{2}{|c|}{ Wald F-statistic }} & 6.25162 \\
\hline F-statistic) & 0.008696 & & & \\
\hline
\end{tabular}

Table 4: Summary of Regression Result

Source: Author's Computation, 2018

\section{Discussion of Findings}

The overall finding of this study is that, there is a significant relationship between agricultural productivity and poverty reduction in Nigeria. This is in line with the theoretical underpinning of the study, that is, resource use efficiency, 
having an expectation that, agricultural productivity will translate to poverty and hunger reduction. It is, also, in support of the findings of Iheke and Arikaibe (2012) and Katsushi (2017): for, Iheke and Arikaibe (2012) found a significant positive relationship between agricultural intensification and poverty reduction in Nigeria. Also, Katsushi (2017) found that, agricultural productivity had significant positive effect on national, rural and urban poverty.

Moreover, this study specifically found a long-run relationship between agricultural productivity and poverty reduction in Nigeria. This is a confirmation of the finding of Eseyin and Oni (2016). The implication of this is that, if agricultural productivity is given priority in Nigeria, this will have long lasting effects on poverty and hunger reduction in the country. Furthermore, this study found that, agriculture budget allocation did not translate to poverty and hunger reduction in Nigeria. This result is at variance with the finding of Udofia and Essang (2015), which showed that, government expenditure had negative relationship with poverty index, meaning that, the more the government expenditure, the less the poverty index, and vice versa. The adducible reason for the finding of this study is that, allocated funds may not have been properly channeled, and may have been diverted to other sectors orhave not been used for the purposes for which they are meant. As such, funds end up in the hands of greedy people within the sector and do not get to the right targets, who are the smallholder and large scale farmers. This is the indication of corruption and misallocation as found by Korankye (2014).

Still, this study found that, commercial banks credit to agriculture did not bring about poverty reduction in Nigeria. The adducible reason for this is that, most smallholder farmers cannot meet the lending requirements of commercial banks unlike those of microfinance banks. Worthy of note is the fact that, this finding is not at tune with the finding of Ogundipe et al (2017), which indicated that, domestic credit to private sector significantly contributed to reduction in rural, urban and dollar poverty in Nigeria. However, this study found that, both microfinance banks credit to agriculture and food production index contributed to poverty and hunger reduction in Nigeria. A careful look at Renuka and Vincent (2015)'s findings shows areas of convergence with the findings of this study.

\section{Conclusion and Recommendation}

The study investigated the effects of agricultural productivity on poverty reduction in Nigeria within a temporal scope of 2000 - 2016. Based on the theoretical framework of resource use efficiency and the findings emanating from this study, using Johansen co-integration test and regression analysis, the study concluded that, there is a long-run relationship between agricultural productivity and poverty reduction in Nigeria, such that, agricultural productivity contributed to the reduction in poverty and hunger in Nigeria.

However, the following recommendations were made. First, the federal government should increase agricultural sector budgetary allocation so as to enhance agricultural productivity and reduce poverty, hunger and food insecurity in the land. Second, budgetary allocation to agriculture should be attributed to encouraging unemployed youths and unskilled labour in the different geo-political zones of the country to embrace agribusiness so as to increase agricultural productivity in Nigeria. Third, government should monitor the budgetary allocation to agricultural sector to ensure that, recurrent budgetary allocations to the sector are not diverted to other sectors, and that funds allocated to the sector are used for the purposes for which they are meant, so that the funds will not end up in the hands of greedy people within the sector. Fourth, regulatory authorities of the Nigerian banking sub-sector should ensure that, commercial banks credit to agricultural sector get to the right targets within the purview of sectorial credit portfolio. Fifth, government should formulate policies that will encourage both commercial and microfinance banks to lend more funds to large scale and small-holder farmers so as to achieve increased agricultural productivity in Nigeria.

\section{References}

i. Abiola, A.G., \& Olaopa, O.R. (2008). Economic development and democratic sustenance in Nigeria. Ibadan: John Archers Publishers Limited.

ii. Abdullahi, A. (2008). Food security in Nigeria: How close are we? A paper presented at the Federal Radio Corporation's Annual Lecture- Abuja 4-6

iii. Adebayo, H. (2017). Special report: How Buhari's agriculture programme is creating jobs, pushing Nigeria towards self-sufficiency in rice. Premium Times, http:www.premiumtimes.com

iv. Ahearn, M., Yee, J., Ball, E.,\& Nehring, R. (1998). Agricultural productivity in the United States. Resource Economics Division, Economic Research Service, U.S. Department of Agriculture. Agriculture Information Bulletin, No. 740

v. Amaka, G., Kenechukwu, O., \& Olisa, D.(2016). Achieving sustainable food security in Nigeria; Challenges and way forward. 3rdInternational Conference on African Development Issues. 182- 189

vi. Asoluka, N.,\& Okezie, A. (2011). Unemployment and Nigeria economic growth: International Conference of Teaching, Learning and Change, Department of Economics, Alvan Ikoku, Federal College of Education, Oweri, Imo State, Nigeria

vii. Auta, S. J., \& Dafwang, I. I. (2010). The Agricultural Development Projects (ADPs) in Nigeria: Status and policy implications. Research Journal of Agriculture and Biological Sciences,6(2), 138-143

viii. Ayodeji, E. A. (2011). Introduction to financial management, Lagos: Emboss Publishers, Foyo Associates Limited.

ix. Central Bank of Nigeria (2016).Statistical Bulletin 19, December, Abuja, Nigeria

x. Daneji, M. I. (2011). Agricultural development intervention programmes in Nigeria (1960 to date): A review. Savannah Journal of Agriculture, Faculty of Agriculture, Bayero University, Kano, 6 (1), 101-107

xi. Diao, X., Hazell, P., \& Thurlow, J. (2010).The role of agriculture in African Development, World Development, 38(10). 1375-1383. 
xii. Eseyin, O., \& Toluyemi, S. T. (2016). Investment in agriculture sector: Implication for poverty

reduction in Nigeria. American Journal of Business and Society, 1(3), 118-128

xiii. Food and Agriculture Organization of the United Nations (2015). The driving action across the 2030 agenda for sustainable development, Rome

xiv. Federal Office of Statistics (1996). The social and economic profile of Nigeria. Lagos: Federal Office of Statistics

xv. Food Production Index in Nigeria (2015). Food production index. Available http:/ / www.indexmundi.com/ facts/ nigeria/ food-production-index. Accessed on 22nd August 2018

xvi. Gate, B. (2014). Agricultural development strategy overview. Annual letter. Available on www.gatesfoundation.org/ What-We-Dwww.gatesfoundation/ Global-Development/ Agricultural-Development retrieved on 22nd August, 2018

xvii. Hanumanthappa K. M. (2014). A clarification of the concept of agricultural productivity in Karnataka. International Journal of Innovative Research and Development. 3(7), 395-397

xviii. Honfoga, B. G., \& Van, D. B. (2003). Food consumption patterns in Central West Africa and challenges to combating malnutrition, Food and Nutrition Bulletin, 24 (2), 167-182

xix. Idachaba, F. (2004). Food security in Nigeria: Challenges under democratic dispensation, Paper presented at ARMTI, Ilorin.

xx. Iheke, O. R., \& Arikaibe, F. A. (2012). Impact of agricultural intensification on poverty alleviation among farm households in Imo State, Nigeria. International Journal of Development and Sustainability, 1(3), 1140-1149

xxi. Imahe, O.J.,\& Alabi, R.A.(2005). The determinants of agricultural productivity in Nigeria. Journal of Food, Agriculture \& Environment. 3 (2), 269-274

xxii. Katsushi, S.I.(2017). Roles of agriculture transformation in achieving sustainable development poverty, hunger productivity and inequality. Discussion paper series, RIEB, Kobe University, 1-61

xxiii. Korankye, A.A. (2014). Causes of poverty in Africa: A review of literature. American International Journal of Social Science, 3(7), 147-153

xxiv. Lawal,H. (2011). Appraising Nigeria agriculture since independence: News Agency of Nigeria, 5 (212), October 6.

xxv. Matemilola S., \& Elegbede, I. (2017). The challenges of food security in Nigeria. Open Access Library Journal, 4(1), $1-22$

xxvi. Medugu, I.N (2006). Achieving sustainable agriculture in Nigeria. A land use policy perspective. Tokyo Academic Industry and Cultural Integration Tour, 10 -19 December, Shibaura Institute of Technology, Japan, 1-11

xxvii. Metu, A.G., Okeyika, K.O.,\& Maduka, O.D.(2016). Achieving sustainable food security in Nigeria. Challenges and way forward. 3rdInternational Conference in African Development Issues, 182-188

xxviii. National Bureau of Statistics (2010): Annual Abstract of Statistics (2010), Abuja, Nigeria.

xxix. National Bureau of Statistics (2016): Annual Abstract of Statistics (2016), Abuja, Nigeria

xxx. Nigeria Poverty Profile 2010 Report (2012). Press Briefing by the Statistician-General of the Federation/ Chief Executive Officer, National Bureau Of Statistics, Dr. Yemi Kale Held At The Conference Room, 5th Floor, NBS Headquarters, Central Business District, Abuja, 1-12

xxxi. Nwankpa, N. N. (2017). Sustainable agricultural development in Nigeria: A way out of hunger and poverty. European Journal of Sustainable Development, 6(4), 175-184

xxxii. Ogbe, N.E. (1984). A review of the Nigerian economy (1960-1983).Bullion. Silver Jubilee Edition, July

xxxiii. Ogundipe, A. A., Oduntan, E. A., Oguniyi, A. I., \& Olagunju, K. O. (2017). Agricultural productivity, poverty reduction and inclusive growth in Africa: Linkages and pathways. Asian Journal of Agricultural extension, economics and sociology, 18(1), 1-15

xxxiv. Ogwumike, F. (1995). The effects of macro-level government policies on rural development and alleviation in Nigeria: Journal of Social Sciences, 1(2), 85-101

xxxv. Ojo, M.O. (1994). Non-oil exports in Nigeria's changing policy dispensation. Bullion, 18(2)

xxxvi. Okunola, A.M. (2016). Positioning rural economy for implementation of sustainable development goals. Turkish Journal of Agriculture, food and science and technology, 4(9), 752-757

xxxvii. Olowa, O.W. (2012). Concept, measurement and causes of poverty: Nigeria in perspective. American Journal of Economics, 29(1), 25-36

xxxviii. Omonijo, D. O.,Toluwase. S. O. W., Oludayo, O. A.,\& Uche, O. O. C. (2015). Impacts of Agricultural Development Programme (ADP) on rural dwellers in Nigeria: A study of Isan-Ekiti. International Research Journal of Finance and Economics, 128, 41-55

xxxix. Oni, L. (2014). An assessment of agriculture and poverty reduction nexus in Nigeria. Journal of Africa Macroeconomic Review. 4(1), 265-284

xl. Onipede, D., \& Ayodeji, E. A. (2005). Economics (A Complete Text on 'O' \& 'A' Level Economics), Ibadan: Kins Publishers Limited

xli. Oriola, E.O.(2009). A framework for food security and poverty reduction in Nigeria. European Journal of Food Social Sciences, 8(1), 132-139

xlii. Otaha, I.J.(2013). Food insecurity in Nigeria. An International Multidisciplinary of Journal Ethiopia, 7(4), 26-35

xliii. Rentilimger, S. (1985). Food security and poverty in less developed countries, Finance and Development Journal, 22(1), 7-22

xliv. Renuka, M., \& Vincent, H. (2015). Link between poverty and food security in Vietnam, 2010- 2015.Social Indicator Research Journal, 15(3), 1-22

xlv. Sumiter, S.B.(2002). Food security, poverty and agriculture: A concept paper. ESA Working Paper, No. 2-15 
xlvi. Toromade, S. (2018). Buhari: Five agriculture initiatives by president's administration he wants Pulse.ng https:/ / www.google.com. Accessed 22nd August, 2018

you to know.

xlvii. Udah, S.C.,\& Nwanchulwu,I.N. (2015). Determinants of agricultural GDP growth in Nigeria. International Journal of Agricultural Research and Review, 3(3), 184-190

xlviii. Udofia, L., \& Essang, N. (2015). Agriculture expenditure and poverty alleviation in Nigeria. European Journal of Business and Management, 7(21), 29-44

xlix. World Bank (1996). Nigeria, poverty in the midst of plenty: The challenge of growth with inclusion. Washington, D. C.: World Bank World Food Programme (2009). Comprehensive Food Security and Vulnerability Analysishttps// documents.wfp.org/ stellent/ groups/ public/ documents/ manual_guide_proced/ wfp20 3208. Accessed22nd August, 2018

1. World Development Indicators (2016).World Development Indicators. Retrieved from http:/ / wdi.worldbank.org/ tables. Accessed 22nd August, 2018 